\title{
Factors Affecting the Production of Stone Fruit (Apricot) in District Mansehra Khyber Pakhtunkhwa, Pakistan
}

\author{
Ahmad Abrar Khan* and Muhammad Idrees
}

Department of Agricultural Extension Education and Communication, The University of Agriculture, Peshawar, Khyber Pakhtunkhwa, Pakistan.

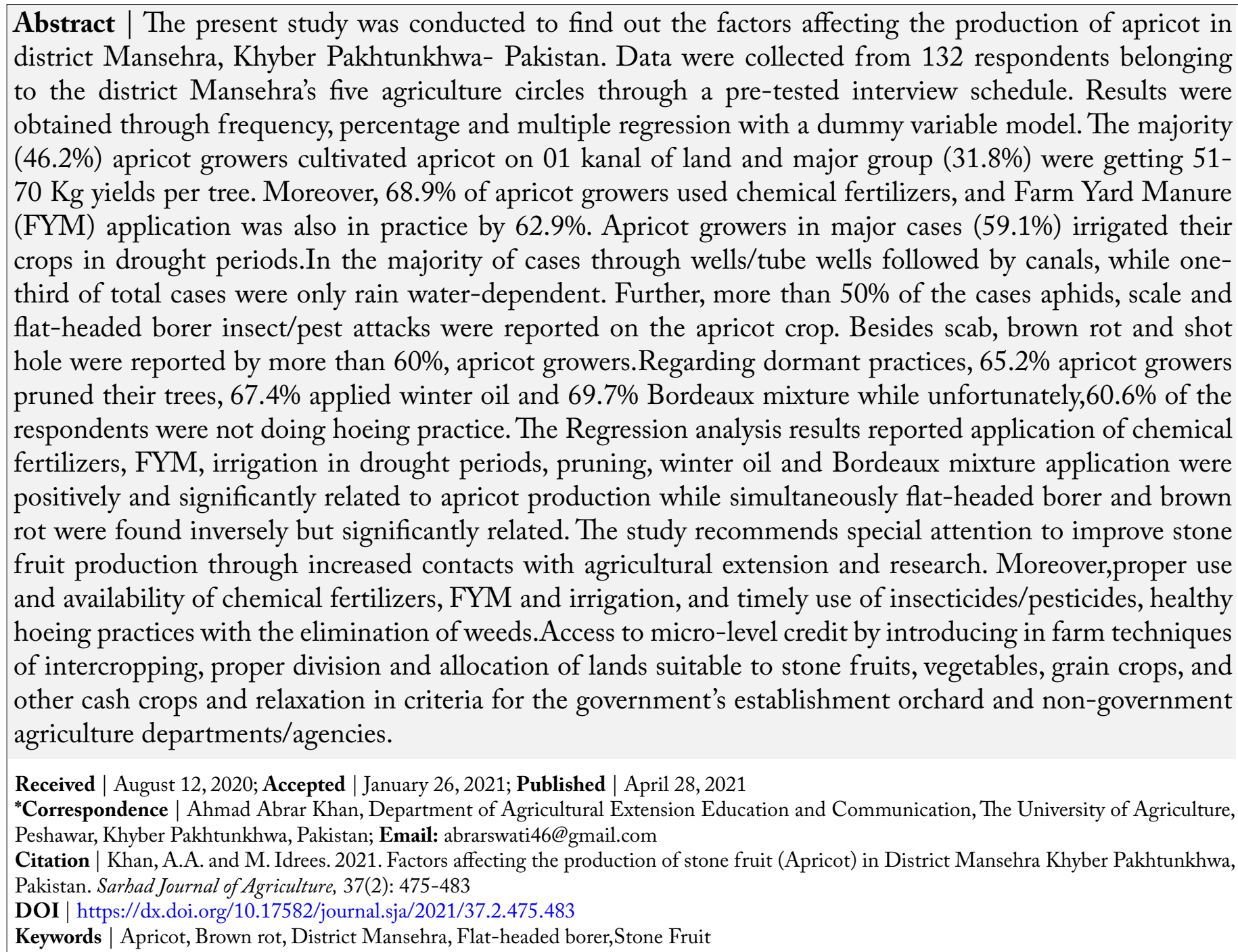

\section{Introduction}

A griculture is still the largest sector of Pakistan's economy in terms of labour participation and as such livelihood of the majority of the population directly or indirectly depends on it. However, during the last few decades, its contribution to GDP has gradually decreased to 19.3 percent however there is 
a lot of potential in the sector to increase its share in GDP through increased productivity and utilization of latest agricultural technologies (GoP, 2020). Fruits are important agriculture product, have the potential to raise the economy of the country. The apricot tree is one of the most important fruit species grown globally since the fruit is highly appreciated by consumers (Roussos et al., 2011). Apricots are referred to stone fruits, belong to a family of drupe fruits, outer fleshy part consists of exocarp and mesocarp (skin and flesh) surrounds a shell (stone) of hardened endocarp with a seed inside. These include apricot, peach, plum, nectarine, almond, and cherry relate closely to each other. Because of large and hard seed, these fruits are commonly referred to as stone fruits. All these belong to the same genus: Prunus, family Rosaceae, order Rosales, class Magoliopsida, and division Magoliophyta (Penn State Extension, 2015). Apricot has unique importance among all stone fruits because of its multifarious compositional shape, structure, and important potentials. Regarding nutritional content of apricot in terms of more than $60 \%$ of sugar, protein, crude fiber, crude fat and total minerals by $8 \%, 11.5 \%$, $2 \%$ and $4 \%$ respectively also having vitamin A, C, K and $\mathrm{B}$ complex and sound amount of organic acids based on the dry weight. The fruit has a great market value as of fresh and dried food commodity and has a remarkable market share of agricultural income (Fatima et al., 2018). According to FAO in the world ranking 2018, Turkey is the leading country in apricot production followed by Uzbekistan and Iran with 750000, 493842 and 342479 tonnes respectively. With 128382 tonnes, Pakistan is on No. $7^{\text {th }}$ globally (FAO, 2018). In Pakistan apricot is produced in three provinces namely Punjab, Khyber Pakhtunkhwa and Balochistan. In the country by the year, 2017-18 area under apricot was 22715 hectares with a production of 141721 tonnes (GoP, 2019). Apricot is produced in 19 out of 25 districts of Khyber Pakhtunkhwa, during the year 2017-18 area under apricot was 2707 hectares with a production of 11218 tonnes. Swat is the leading district with 1160 tonnes, followed by Peshawar district with 1130 tonnes and Nowshera district with the production of 1080 tonnes (CRS, 2019). The climate of most of the districts of province Khyber Pakhtunkhwa suits stone fruits culture including district Mansehra. Cultivation of apricot is very sluggish and stagnant while cultivating short life cycle vegetables, i.e. tomato, cauliflower, potato, pea, onion, legumes and cereal crops wheat and maize are common in the district. By the year 2017-18, apricot production was 209 tonnes with a yield of 5.8 tonnes per hectare. Mansehra district ranks at No. $10^{\text {th }}$ in apricot production. Public sector agriculture extension and agriculture research departments in the district are working to enhance stone fruit production and orchards developments (CRS, 2019).

The declining trend of fruit crop cultivation and rising trend of vegetables and other cash crops were observed from the past few decades. In such circumstances, the government started fruits orchards expansion and development projects to uplift the production and bring back the trend of fruits cultivation. Some projects under the umbrella of agricultural extension and agricultural research departments were initiated. About 1000 acres of land at different site of the district was brought under fruits orchards including apricot (ARS, 2009; Crops' Orchards Reports, 2015).

Fruits are important agriculture product play their role in raising the economy of the country. In rural areas, fruit cultivation is a good source of income and provides livelihood opportunities in seasonal days. Having suitable climatic conditions the yield of apricot in district Mansehra is lower than the other districts of the province, i.e. Bunir, Charsada, Dir lower, Dir upper, Hangu, Nowshera and Swat (CRS, 2019). Although, agricultural extension and agricultural research departments are working on the development and enhancement of stone fruit cultivation in the district but production, yield and rank of the stone fruit are not so impressive. There is a special need for an investigation of the problems responsible for low production in the district. Proper guidance, appropriate agriculture technology for farm management practices are very important. This study was initiated to investigate the factors which are affecting the apricot production in the district.

\section{Materials and Methods}

This research study was conducted in district Mansehra located in East west mountains zone of Khyber Pakhtunkhwa Province of Pakistan. The multistage sampling procedure was used to draw the requisite sample for the current study. Public sector agricultural extension department divided the district into six circles, out of which five circles, i.e. Mansehra I, Oghi, Baffa and Balakot were selected purposively. The circle Mansehra II was excluded because of the diverse population and limitation of data collection 
time (Crops'Orchards Reports, 2015). The population of apricot growers for each selected circle was taken from district directorates of agricultural extension and agricultural research departments working in the district. The total population of apricot growers was 195 for which a sample of 132 apricot growers was taken through Sekaran (2006) sample size table. From each circle, farmers were selected through a proportional allocation technique.Mathematically proportional allocation technique is expressed in Equation 1.

$$
n i=N i \times n / N \quad \ldots(1)
$$

Whereas in the above equation ni is used to represent the required sample of apricot growers in the $i$ th circle, $\mathrm{Ni}$ is used to represent the total population of apricot growers in the $i$ th circle, $\mathrm{n}$ is used to represent the total sample size of the research study, and $\mathrm{N}$ is used to represent the total number of apricot growers in the research area.

\section{Collection of data}

In light of the objectives of the study, a well-structured interview schedule was developed. An interview schedule was pre-tested in a pilot phase. Each and every farmer of the study was interviewed personally by the researcher to collect the required data and information.

\section{Data analysis}

Simple data analysis included frequency distribution with percentages. In regression analysis, the dependent variable is not only influenced by the quantitative variable, but also qualitative variable has some effect on the said variable. The presences or absence of an attribute is also an indication of such a variable. The method to calculate such an attribute takes the values of 0 or 1 showing the absence and presence, respectively, called dummy variable (Gujarati, 2004). In order to examine the influence of independent variables (i.e. fertilizers application, farmyard manure application, irrigation in drought, insect/pest attacks, diseases attacks and dormant practices) on dependent variable (i.e. the average per tree yield of apricot) regression model with dummy variable approach was applied. The specific form of the model is given in Equation 2.

$$
\begin{gathered}
Y=\beta_{0}+\beta_{1} D_{1}+\beta_{2} D_{2}+\beta_{3} D_{3}+\beta_{4} D_{4}+\beta_{5} D_{5}+\beta_{6} D_{6} \\
+\beta_{7} D_{7}+\beta_{8} D_{8}+\beta_{9} D_{9}+\beta_{10} D_{10}+\beta_{11} D_{11}+\beta_{12} D_{12}+ \\
\beta_{13} D_{13}+\beta_{14} D_{14}+\varepsilon_{i} \ldots \ldots(2)
\end{gathered}
$$

Where;

$\mathrm{Y}=$ Average per tree yield of apricot, $\mathrm{D}_{1}=$ Dummy for application of chemical fertilizers; 1 for Yes, 0 for otherwise, $\mathrm{D}_{2}=$ Dummy for application of farm yard manure; 1 for Yes, 0 for otherwise, $\mathrm{D}_{3}=$ Dummy for irrigation in drought periods; 1 for Yes, 0 for otherwise, $\mathrm{D}_{4}=$ Dummy for aphids attack; 1 for Yes, 0 for otherwise, $D_{5}=$ Dummy for scale attack; 1 for Yes, 0 for otherwise, $\mathrm{D}_{6}=$ Dummy for flat-headed borer attack; 1 for Yes, 0 for otherwise, $D_{7}=$ Dummy for fruit fly attack; 1 for Yes, 0 for otherwise, $D_{8}=$ Dummy for scab attack; 1 for Yes, 0 for otherwise, $\mathrm{D}_{9}=$ Dummy for brown rot attack; 1 for Yes, 0 for otherwise, $\mathrm{D}_{10}=$ Dummy for shot hole attack; 1 for Yes, 0 for otherwise, $D_{11}=$ Dummy for pruning; 1 for Yes, 0 for otherwise, $\mathrm{D}_{12}=$ Dummy for hoeing; 1 for Yes, 0 for otherwise, $\mathrm{D}_{13}=$ Dummy for application of winter oil; 1 for Yes, 0 for otherwise, $D_{14}=$ Dummy for application of Bordeaux mixture; 1 for Yes, 0 for otherwise. $\beta_{0}=$ Intercept, $\varepsilon_{\mathrm{i}=}$ Error term.

\section{Results and Discussion}

The apricot growers were inquired about the size of land dedicated for apricot cultivation. Data on this aspect is presented in Table 1 . The table shows that most (46.2\%) farmers were cultivating apricot on 1 kanal of land, followed by $22.7 \%$ who were cultivating $1.5 \mathrm{kanal}$ of land. Minimum respondents (6.1\%) were cultivating apricot on 3 kanals of land. This shows that apricot farming in the study area is a part-time job for farmers, and its cultivation is very limited. The stone fruits are cultivated on small sizes of lands in the study area as compared to other areas of the province as reported by Khan et al. (2010) the farm size (in acres) of the respondents from the districts of Nowshera, Peshawar and Charsada, Khyber Pakhtunkhwa province were categorized into five categories, i.e. $0.5-5,5.1-15,15.1-25,25.1-35,35.1$ and above. A majority, i.e. $45 \%$ of model fruit growers area of cultivation was 35.1 acres and above.

Production depends on the variety grown and farm management practices. Generally, in apricot farming, yield up to $90 \mathrm{Kg}$ and above per tree can be obtained (ARS, 2010). Farmers were inquired about their total production from apricot trees, and then the average per tree yield was obtained from the data collected in the study area. Table 2 indicates that the maximum average per tree yield of $80 \mathrm{Kg}$ was recorded in the study area, while the recommended yields are up to 
$90 \mathrm{Kg}$ in the study area. Majority (31.8\%) apricot growers' average per tree yield was $61-70 \mathrm{Kg}$ followed by $16.7 \%$ who obtained $71-80 \mathrm{Kg}, 18.2 \%$ got $21-$ $30 \mathrm{Kg}, 14.4 \%$ were having $51-60 \mathrm{Kg}, 12.1 \%$ had $31-40 \mathrm{Kg}$, and $6.8 \%$ obtained $41-50 \mathrm{Kg}$. There are collectively $46.2 \%$ apricot growers in the study area who were unable to get average per tree yield above $70 \mathrm{Kg}$, which is very disappointing. The average per tree yield of apricot in the study area is below the recommended optimum line, and there is a big gap between current yield and optimum recommended yield of stone fruits. There may be many factors involved in the low production of apricot fruits in the area. This may be possibly due to stone fruit cultivation's inappropriate management and practices in many aspects like fertilizers application, irrigation, insect pest, and diseases.

Table 1: Distribution of respondents' land under apricot cultivation.

$\begin{array}{lll}\text { Area in Kanals } & \text { Frequency } & \text { Percent } \\ 1 \text { Kanal } & 61 & 46.2 \\ 1.5 \text { Kanal } & 30 & 22.7 \\ 2 \text { Kanals } & 24 & 18.2 \\ 2.5 \text { Kanals } & 9 & 6.8 \\ \text { 3 Kanals } & 8 & 6.1 \\ \text { Total } & 132 & 100.0\end{array}$

Source: Field survey.

Table 2: Distribution of respondent regarding average per tree yield of apricot.

\begin{tabular}{|lll|}
\hline Average per tree yield & Frequency & Percent \\
$21-30 \mathrm{Kg}$ & 24 & 18.2 \\
$31-40 \mathrm{Kg}$ & 16 & 12.1 \\
$41-50 \mathrm{Kg}$ & 9 & 6.8 \\
$51-60 \mathrm{Kg}$ & 19 & 14.4 \\
$61-70 \mathrm{Kg}$ & 42 & 31.8 \\
$71-80 \mathrm{Kg}$ & 22 & 16.7 \\
Total & 132 & 100 \\
\hline
\end{tabular}

Source: Field survey.

Table 3 indicates that the majority (68.9\%) apricot growers were applying chemical fertilizers, whereas $31.1 \%$ were not applying. In the case of farmyard manure (natural fertilizers), the majority (62.9\%) were applying farmyard manureand rest $37.1 \%$ did not apply. The study results are in line with Javeid (2019), who reported that more than $50 \%$ of the respondents applied natural fertilizers to their orchards. More than two-thirds (68.9\%) and 62.9\% of the respondents were recorded with the application of chemical fertilizers and farmyard manure respectively, but unfortunately,a big gap of knowledgewas found aboutrecommended doses and basicprimary nutrients $(\mathrm{N}, \mathrm{P}, \mathrm{K})$ of chemical fertilizers and farmyard manure. Apricotgrowers were unable to inform about the type of chemical fertilizers they have used. Chemical fertilizers application and doses were in practice on fertiliser dealers and shopkeepers' recommendations and suggestions while farmyard manure application by their own and fellowfarmers' choice. Patel and Vyas (2014) reported that 70\% of knowledge gap existed in applying basic primary nutrient of fertilizer. Farooq et al. (2019) found 37.0\% knowledge gap index about recommended farmyard manure application.

Table 3: Distribution of respondent regarding the application of chemical and natural fertilizers.

$\begin{array}{llll}\text { Fertilizers } & \text { Status } & \text { Frequency } & \text { Percent } \\ \begin{array}{l}\text { Chemical ferti- } \\ \text { lizer }\end{array} & \text { Yes } & 91 & 68.9 \\ & \text { No } & 41 & 31.1 \\ \text { Farmyard ma- } & \text { Total } & 132 & 100.0 \\ \text { nure } & \text { Yes } & 83 & 62.9 \\ & \text { No } & 49 & 37.1 \\ & \text { Total } & 132 & 100.0\end{array}$

Source: Field survey.

Table 4 depicts that majority (59.1\%) apricot growers irrigated their crops in drought conditions, and 40.9\% did not irrigate. Farmers who were having irrigation sources other than rainwater irrigated their crops in drought conditions. Majority of farmers' source of irrigation was well/tub well while the canal irrigation facility was available to farmers living in plain areas of the district. According to farmers, irrigation through well and tube well is an expensive, time consuming and laborious irrigation method.

Table 4: Distribution of respondent regarding irrigation status in drought conditions.

$\begin{array}{lll}\text { Irrigation in drought conditions } & \text { Frequency } & \text { Percent } \\ \text { Yes } & 78 & 59.1 \\ \text { No } & 54 & 40.9 \\ \text { Total } & 132 & 100\end{array}$

Source: Field survey.

Table 5 shows that majority (59.1\%) apricot growers faced flat-headed borer attack while $40.9 \%$ did not face followed by $57.6 \%$ who faced aphids attack while 
$42.4 \%$ did not face, scale attack was reported by $52.3 \%$ respondents while $47.7 \%$ reported no attack, regarding fruit fly $45.5 \%$ reported its attack while $54.5 \%$ reported no attack of a fruit fly. The study's findings are in line with the Khan et al. (2012) who reported that the attack of aphids and its yield losses were recorded a high population of aphids were damaging the crops. Layton and Henn (2014) reported that infestation of scale attack with the symptoms of crusty, irregular, white or brown patches on branches and twigs. Zahid et al. (2015) found an infestation of flat-headed borer in apricot, peach and plum orchards in the three districts of Khyber Pakhtunkhwa.

Table 5: Distribution of respondent regarding insect/pest attack.

\begin{tabular}{llll}
\hline Insect/pest & Attack status & Frequency & Percent \\
Aphids & Yes & 76 & 57.6 \\
& No & 56 & 42.4 \\
& Total & 132 & 100.0 \\
Scale & Yes & 69 & 52.3 \\
& No & 63 & 47.7 \\
Flat-headed & Total & 132 & 100.0 \\
borer & Yes & 78 & 59.1 \\
& No & 54 & 40.9 \\
Fruit fly & Total & 132 & 100.0 \\
& Yes & 60 & 45.5 \\
& No & 72 & 54.5 \\
& Total & 132 & 100.0
\end{tabular}

Source: Field survey.

Table 6 shows that majority $(72.7 \%)$ apricot growers said that they faced brown rot disease while $27.3 \%$ did not face followed by $62.1 \%$ who faced shot hole while $37.9 \%$ did not face, scab attack was reported by $59.8 \%$ apricot growers while 40.2 reported that they did not face. Scab, brown rot and shot hole were found significant diseases in the study area damaging the production. Khalil et al. (2014) founda huge loss caused by scab and brown rot diseases, reported by the farmers.

Dormant practices help diminish the residues of insects/pest and disease-causing pathogens. These practices contribute to plant growth and toget high production. Table 7 indicates the dormant practices of apricot growers. Majority (69.7\%) respondents said they applied Bordeaux mixture to their trees while $30.3 \%$ did not apply followed by $67.4 \%$ who applied winter oil while $32.6 \%$ did not apply, $65.2 \%$ apricot growers did pruning practice while $34.8 \%$ did not do this practice. Majority (60.6\%) respondents did not do hoeing practice while $39.4 \%$ did hoeing practice. Dormant practices except hoeing were in practice by a more than one-third of the apricot growers. Zahid et al. (2015) concluded that Bordeauxmixture treatment applied to tree trunks effectively reduced the borer infestations. Chaudhary et al. (2012) reported that significantly low incidence of bacterial leaf blight was recorded when Bordeaux mixture alone and in combination with oxytetracycline and then streptomycin were applied. The research study results are supported by the findings of Kallestad et al. (2008) who reported that more than half of the orchards were pruned using mechanical hedging machines, while the other was either pruned entirely by hand or used both methods. The study results are also supported by Hinge's (2009) findings, who reported that a large majority of the farmers followed summer and winter pruning.

Table 6: Distribution of respondent regarding diseases attack.

$\begin{array}{llll}\text { Insect/pest } & \text { Attack status } & \text { Frequency } & \text { Percent } \\ \text { Scab } & \text { Yes } & 79 & 59.8 \\ & \text { No } & 53 & 40.2 \\ & \text { Total } & 132 & 100.0 \\ \text { Brown } & \text { Yes } & 96 & 72.7 \\ \text { rot } & \text { No } & 36 & 27.3 \\ & \text { Total } & 132 & 100.0 \\ \text { Shot hole } & \text { Yes } & 82 & 62.1 \\ & \text { No } & 50 & 37.9 \\ & \text { Total } & 132 & 100.0\end{array}$

Source: Field survey.

\section{Effects of fertilizers on production}

Table 8 reveals estimates of regression analysis of fertilisers' influence on average per tree yield of apricot. The chemical fertilizers and farmyard manure applications to apricot trees have statistically significant positive effects on average per tree yield of apricot. The apricot growers who applied chemical fertilizers and farmyard manure to their apricot trees got 9.792 and $6.173 \mathrm{Kg} /$ tree, respectively more yields than those who did not apply chemical and natural fertilizers. The reason might be that fertilizers dealers and shopkeepers have good knowledge about the right selection of chemical fertilizers which play a key role in the enhancement of the stone fruits production in the study area but still there is a need of applications 
of these fertilizers on the basis of soil analysis and recommendations of agricultural extension experts. The results are in line with Rettke et al. (2006) who reported that orchard with fertilizer application having macronutrients of Nitrogen $(\mathrm{N})$, Phosphorus $(\mathrm{P})$ and Potassium $(\mathrm{K})$ significantly increased the fruit yield and fruit size as compared to control orchard.

Table 7: Distribution of respondent regarding dormant practices.

$\begin{array}{llll}\text { Practices } & \text { Status } & \text { Frequency } & \text { Percent } \\ \text { Pruning } & \text { Yes } & 86 & 65.2 \\ & \text { No } & 46 & 34.8 \\ & \text { Total } & 132 & 100.0 \\ \text { Hoeing } & \text { Yes } & 52 & 39.4 \\ & \text { No } & 80 & 60.6 \\ & \text { Total } & 132 & 100.0 \\ \text { Winter oil } & \text { Yes } & 89 & 67.4 \\ \text { application } & \text { No } & 43 & 32.6 \\ & \text { Total } & 132 & 100.0 \\ \text { Bordeaux } & \text { Yes } & 92 & 69.7 \\ \text { application } & \text { No } & 40 & 30.3 \\ & \text { Total } & 132 & 100.0\end{array}$

Source: Field survey.

\section{Effects of Irrigation on production}

Regression estimation in Table 8 further indicates that farmers who irrigated their apricot trees in drought periods got a significant increase in yield by $6.642 \mathrm{Kg} /$ tree than those who did not irrigate. These were the farmers who had irrigation sources like well, tube well and canal irrigation system and were not dependent only on rainwater. The results are supported by Bozkurt et al. (2015) findings which reported that the irrigation interval treatments had significant effects on trunk diameters and branch lengths of the trees. Increase in yield and fruit size was noticed with an increase in irrigation.

\section{Effects of insect/pest attacks on production}

Regression analysis results in Table 8 indicate that attacks of insects/pests, i.e. aphids, scale and fruit fly were foundnon-significant while apricot growers whose crops were attacked by flat-headed borer got a significant decrease in yield by $3.136 \mathrm{Kg} /$ tree. This might be due to reliance on cultural, physical control methods and lack of hoeing practices. Moreover, there is a late application of chemical treatments and a lack of follow-up treatments to control flat-headed borers. The results are in line with Tirkey et al. (2019), who stated that the infestation of flat-headed borer was significantly higher than other bark eating pest. Significant reduction in the branches was recorded due to flat-headed borer infestation.

Table 8: Regression analysis of the influence of the independent variables on average per tree yield of apricot.

\begin{tabular}{|c|c|c|c|c|}
\hline Independent variables & $\begin{array}{l}\text { Coeffi- } \\
\text { cients }\end{array}$ & $\begin{array}{l}\text { Std. } \\
\text { Error }\end{array}$ & t-ratio & $\mathbf{P}$-value \\
\hline (Constant) & 38.079 & 3.644 & 10.45 & $0.000^{* *}$ \\
\hline $\begin{array}{l}\text { Chemical fertilizers } \\
\text { application }\left(\mathrm{D}_{1}\right)\end{array}$ & 9.792 & 2.188 & 4.476 & $0.000^{* *}$ \\
\hline $\begin{array}{l}\text { Farm yard manure } \\
\text { application }\left(D_{2}\right)\end{array}$ & 6.173 & 1.822 & 3.388 & $0.001^{* *}$ \\
\hline Irrigation in drought $\left(\mathrm{D}_{3}\right)$ & 6.642 & 2.348 & 2.829 & $0.006^{* *}$ \\
\hline Aphids attack $\left(\mathrm{D}_{4}\right)$ & -0.542 & 1.45 & -0.374 & 0.709 \\
\hline Scale attack $\left(\mathrm{D}_{5}\right)$ & -1.019 & 1.81 & -0.563 & 0.575 \\
\hline $\begin{array}{l}\text { Flat headed borer attack } \\
\left(D_{6}\right)\end{array}$ & -3.136 & 1.484 & -2.113 & $0.037^{*}$ \\
\hline Fruit fly attack $\left(D_{7}\right)$ & -0.983 & 1.829 & -0.538 & 0.592 \\
\hline Scab attack $\left(D_{8}\right)$ & -1.552 & 1.446 & -1.073 & 0.285 \\
\hline Brown rot attack $\left(\mathrm{D}_{9}\right)$ & -3.597 & 1.537 & -2.34 & $0.021^{*}$ \\
\hline Shot hole attack $\left(D_{10}\right)$ & -1.728 & 1.481 & -1.167 & 0.246 \\
\hline Pruning $\left(\mathrm{D}_{11}\right)$ & 4.12 & 1.441 & 2.86 & $0.005^{* *}$ \\
\hline Hoeing $\left(\mathrm{D}_{12}\right)$ & 2.317 & 1.272 & 1.822 & 0.071 \\
\hline $\begin{array}{l}\text { Winter oil application } \\
\left(\mathrm{D}_{13}\right)\end{array}$ & 3.983 & 1.381 & 2.885 & $0.005^{* *}$ \\
\hline $\begin{array}{l}\text { Bordeaux mixtures } \\
\text { application }\left(D_{14}\right)\end{array}$ & 4.286 & 1.695 & 2.528 & $0.013^{*}$ \\
\hline
\end{tabular}

"indicates significance and * bigh significance at $P \leq 0.05$ and $P \leq 0.01$, respectively; $R$-square: 0.894 ; Adjusted $R$-square: $0.881 ; F$ stat: 70.605 ; Source: Authors' estimation based on field survey data.

\section{Effects of diseases attacks on production}

Table 8 also shows the regression estimation regarding attacks of diseases, i.e. scab and shot hole are non-significant while apricot growers who faced the brown rot attack got a significant reduction in yield by $3.597 \mathrm{Kg} /$ tree as compared to those who did not face an attack of brown rot. Lack of follow up chemical treatments is the reason for brown rot damages. Brown rot is present in all temperate regions and is responsible for important economic losses of stone fruits reported by Oliveira et al. (2016).

\section{Effects of dormant practices on production}

The regression analysis results in Table 8 further show that dormant practices; pruning, winter oil and Bordeauxe mixture application have significant positive on average per tree yield of apricot. Farmers who pruned their trees, applied winter oil and 
Bordeaux mixture to their trees obtained $4.12 \mathrm{Kg}$, $3.983 \mathrm{Kg}$ and $4.286 \mathrm{Kg}$ more yield as compared to those who did not do these dormant season practices while hoeing was found non-significant. The reason may be that farmers efficiently do theses dormant practice except hoeing, which is more laborious and time-consuming field operation as compared to other dormant practices. The study results are supported by Cebula's (1995) findings, who stated that pruning plants to 2, 3 or 4 shoots was reported to be effective in increasing yield and fruit size.

\section{Conclusions and Recommendations}

It is concluded from the study that apricot cultivation was a less common activity of the farming community in district Mansehra. In spite of the major trend of the farming community towards the other cash crops such as vegetables and tobacco, stone fruits are still grown in the study area. The majority were getting average per tree yield between $51-70 \mathrm{Kg}$. Farmers in major cases were highly dependent on chemical fertilizers, farmyard manure and irrigation. The facility of canal irrigation was available to less than one-third of the total stone fruit growers. In more than one-third of the respondents were only rainwater-dependent. Aphids, scale and flat-headed borer were the three major attacks of insects/pests while regarding diseases brown rot attacked the apricot than scab and shot hole. With respect to dormant season practices, twothird of the respondents pruned their trees, winter oil and Bordeaux mixture while hoeing practice by less than half of the apricot growers. This is further supplemented through the significant and positive relationship of stone fruits production with the application of chemical fertilizers, farmyard manure, irrigation in drought periods, pruning, winter oil and Bordeaux mixture application. At the same time, flat-headed borer and brown rot significantly and inversely affected the apricot production. Special attention is needed to enhance the production of stone fruits through increased and improved contacts with agricultural extension, agricultural research and other relevant departments or agencies for the proper and efficient application of chemical fertilizer farmyard manure, especially to those who are not availing or applying the agricultural inputs along with their proper dose and time recommended on the basis of soil analysis by the relevant agricultural departments. Most of the study area farmers were dependent on well/tube well followed by only rainwater for irrigation purpose. The canal irrigation system of
River Siran should be expanded to remaining plain areas of the district and the creation of a new canal irrigation system over River Kunhar, as River Kunhar has more water than Siran must be utilized for agricultural purposes. Moreover providing the facility of well/tube wells other irrigation equipment along with the construction of water tanks at foothills to store the rainwater can also address the drought and other irrigation problems of the apricot growers.Lack of safety sprays and follow-up treatments and the late applications of chemicals against and improper timing were the causes of attacks of insects/pests and diseases. It is recommended to spray on the proper time, and follow-up sprays especially to meet the danger of aphids, scale, flat-headed borer, fruit fly, scab, brown rot and shot hole. Reliance only on physical control method had increased the infestation of the pests. This should be properly checked and implemented through organizing integrated pest management and control (IPM and C) programs, workshops and field activities. The production can further be improved through pruning, hoeing, winter oil and Bordeaux mixture application along with proper scientific guidance and management about these practices. To enable the stone fruit growers to use the inputs and other measures, small credit schemes should be introduced to enable them to get the required agricultural inputs. The study area was/is still one of the main stone fruit producing areas in suitable conditions. In order to check the decline of farming community trend towards stone fruit production and cultivation, special attention is needed to grow the stone fruit trees not only the sides of farms but also adjoining hillsides. This will enable the farmers to grow the vegetable and other cash crops and motivate them to plant fruit trees on those areas that were not under cultivation. Intercropping with efficient farm management can be an effective tool for increasing stone fruits cultivation along with motivation of farmers towards the proper division of lands for stone fruits, grain crops, vegetables and other cash crops in order to enable the equal and balanced supply of all agricultural products to the market is necessary for the favour of farmers and country as well.Criteria of 8 kanals of land mandatory for establishing orchard by the government and non-government agriculture departments/agencies should be relaxed.

\section{Novelty Statement}

The present study was conducted to find out factors affecting the production of stone fruit (apricot) in 
district Mansehra of Khyber Pakhtunkhwa province. Before this no such study was conducted on this topic in the study area. Findings and recommendations of the study will be helpful to enhance the production of stone fruit.

\section{Author's Contribution}

Ahmad Abrar Khan is a PhD scholar who researched, collected data, made all analysis, and wrote the manuscript's $1^{\text {st }}$ draft. Muhammad Idrees supervised the whole study.

\section{Conflict of interest}

The authors have declared no conflict of interest.

\section{References}

ARS, 2009. Annual report. Horticulture section. Orchards exploitation. Agriculture research station Baffa, Mansehra. KP Agric. Res. Syst., pp. 3-4.

Bozkurt, S., B. Ödemiş and C. Durgaç. 2015. Effects of deficit irrigation treatments on yield and plant growth of young apricot trees. N.Z.J. Crop Hortic. Sci., 43(2): 73-84. https://doi.org/ 10.1080/01140671.2014.979838

Cebula, S., 1995. Optimization of plant and shoot spacing in greenhouse production of sweet pepper. Acta Hortic., 412(1): 321-329. https:// doi.org/10.17660/ActaHortic.1995.412.37

Chaudhary, S.U., J. Iqbal and M. Hussain. 2012. Effectiveness of different fungicides and antibiotics against bacterial leaf blight in rice. J. Agric. Res., 50(1): 109-117.

Crops' Orchards Reports, 2015. District directorate of agricultural extension Mansehra, KP. pp. 3-10.

CRS, 2019. Final estimate of fruits production. KP. Fruits District Wise Kharif and Rabi. Crop Reporting Service Centre. Directorate of Agril. Ext. KP, Peshawar. Pakistan. pp. 17-18.

FAO, 2018. Food and agricultural organization. Rankings. Countries by commodity. Apricot. http://www.fao.org/faostat/en/\#rankings/ countries_by_commodity.

Farooq, A., M.Z. Khan, A. Hassan, M. Ishaq and A. Nawaz. 2019. Knowledge gap analysis of sugarcane growers in recommended sugarcane production technology in Khyber Pakhtunkhwa, Pakistan. Int. J. Biosci., 15(1): 87-98.
Fatima, T., O. Bashir, G. Hani, T.A. Bhat and N. Jan. 2018. Nutritional and health benefits of apricots. Int. J. Univ. Integr. Med., 2(2): 05-09.

GoP, 2019. Government of Pakistan. Economic survey 2018-19. Finance Division. Economic Adviser's Wing, Islamabad, http://www.finance. gov.pk/Supplement_2018_19.pdf .

GoP, 2020. Highlights of Pakistan economic survey 2019-20. Chapter 2-Agriculture. Economic Adviser's Wing, Finance Division. GoP. Islamabad. pp. 17.

Gujarati, D.N., 2004. Basic econometrics: International edition. $3^{\text {rd }}$ ed., Me Graw Hill Book Co., New York. pp. 47-50.

Javeid, S. 2019. Impact of apple orchards development through extension services on poverty reduction in AJK. Ph.D. Thesis, submitted to the Department of Agricultural Extension Education and Communication. The University of Agriculture, Peshawar. pp. 53.

Hinge, R.B., 2009. A study on diffusion and adoption of wine grape production technology in Maharashtra (Doctoral dissertation, UAS, Dharwad).Pg. 26.

Kallestad, J.C., J.G. Mexal and T.W. Sammis. 2008. Mesilla valley pecan orchard pruning residues: Biomass estimates and value-added opportunities. New Mexico State University, Agricultural Experiment Station. pp. 6.

Khalil, I., M. Idrees, F. Rabi, S. Rehman and N. Bostan. 2014. An investigation into the problems of peach growers in district Swat. ARPN J. Agric. Biol. Sci., 9(12): 427-434.

Khan, N., M. Israr, N. Shah, M. Arif, M. Naeem, S. Naz, Z. Haq and A. Ali. 2010. A comparative study of model and non-model fruit growers in rural areas of Khyber Pukhtunkhwa Pakistan. Sarhad J. of Agric., 26: 641-647

Layton, B. and R.A. Henn. 2014. Disease and insect control for homegrown peaches and plums. Mississippi State Univ. Ext Ser., pp. 2.

Oliveira, L.L., I. Pacheco, V. Mercier, F. Faoro, D. Bassi, I. Bornard and B. Quilot-Turion. 2016. Brown rot strikes Prunus fruit: An ancient fight almost always lost. J.Agric. Food Chem., 64(20): 4029-4047. https://doi.org/10.1021/acs. jafc.6b00104

Patel, A.G. and H.U. Vyas. 2014. Technological gap in adoption of sugarcane cultivation practices by sugarcane growers. Gujarat J. Ext. Edu., 25(2): $227-229$. 
Penn State Extension, 2015. Penn state extension plants and pests. Home lawn and garden. Fruit production for the home gardener stone fruits: Peaches, Nectarines, Plums, Apricots and Cherries. Penn State College of Agriculture Sciences. Pennsylvania. USA. http://www. extension,psu.edu/plants/gardening/fphg/ stone.

Rettke, M.A., T.R. Pitt, N.A. Maier and J.A. Jones. 2006. Growth and yield responses of apricot (cv. Moorpark) to soil-applied nitrogen. Austral. J. Exp. Agric., 46(1):115-122.

Roussos, P.A., V. Sefferou, N.K. Denaxa, E. Tsantili and V. Stathis. 2011. Apricot (Prunusarmeniaca L.) fruit quality attributes and phytochemicals under different crop load. Sci. Hortic., 129: 472-478. https://doi.org/10.1016/j. scienta.2011.04.021

Sekaran, U., 2006. Research methods for business. USA, Harnitage Publishing Services. pp. 468.

Tirkey, P., M. Chandrashekharaiah, M.S. Rathore, R.K. Singh, R.B. Sinha and A. Sahay. 2019. Studies on level of infestation of flat headed borer and bark eating caterpillar on terminaliaarjuna and their management using insecticides. Int. J. Curr. Microbiol. App. Sci., 8(1): 598-605. https://doi.org/10.20546/ijcmas.2019.801.067

Zahid, M., M. Salman, S.A. Khan, Alamzeb and I. Khan. 2015. Surveillance and control of peach flat-headed borer, Sphenopteradadkhani (Oben.) in Plum orchards of Khyber Pakhtunkhwa, Pakistan. Sarhad J. Agric., 31(1): 1-7. 